\title{
Hunter-Gatherer Variability: Developing Models for the Northern Coasts
}

\author{
Peter Rowley-Conwy ${ }^{1,2}$ and Stephanie Piper ${ }^{1}$
}

(Received 2 March 2016; accepted in revised form 4 August 2016)

\begin{abstract}
Hunter-fisher-gatherer (HFG) variability has received a lot of attention. We review the key developments in the theories of variability, which have usually resulted in binary classifications. We argue that a range of variation based on the degree of territorial ownership is preferable to these classifications. Hunter-fisher-gatherers of the world's northern coasts have only been partially explored in this way with regard to variability. A major reason for this is that such coastal groups use boats, so normative models of inland terrestrial foraging are not immediately applicable. We suggest that the Saxe-Goldstein hypothesis, the cautious linking of territoriality to funerary behaviour, may be a useful avenue to explore. Much work has been done by scholars of the northern coasts on boats and maritime transport, and some conclusions could be extrapolated to regions farther south.
\end{abstract}

Key words: hunter-fisher-gatherers; variability; foragers; collectors delayed return; Saxe-Goldstein hypothesis; cemetery; mobility

RÉSUMÉ. La variabilité caractérisant les chasseurs-pêcheurs-cueilleurs (CPC) reçoit beaucoup d'attention. Nous passons en revue les principaux développements en ce qui a trait aux théories de la variabilité, qui se traduisent habituellement par des classifications binaires. Nous soutenons qu'une plage de variations fondée sur le degré de propriété territoriale est préférable à ces classifications. La variabilité caractérisant les chasseurs-pêcheurs-cueilleurs des côtes nord de la planète n’a été étudiée qu'en partie. Cela s'explique majoritairement par le fait que ces groupes côtiers se servent d'embarcations, si bien que les modèles normatifs de recherche de nourriture à l'intérieur des terres ne sont pas immédiatement applicables. Nous suggérons que l'hypothèse de Saxe-Goldstein, soit le lien prudent entre la territorialité et le comportement funéraire, pourrait présenter une piste valant la peine d'être explorée. Les spécialistes des côtes nord ont beaucoup étudié le transport maritime et le transport au moyen d'embarcations, si bien qu'il pourrait être possible d'extrapoler certaines conclusions quant aux régions situées plus au sud.

Mots clés : chasseurs-pêcheurs-cueilleurs; variabilité; recherche de nourriture; retour tardif des cueilleurs; hypothèse de Saxe-Goldstein; cimetière; mobilité

Traduit pour la revue Arctic par Nicole Giguère.

\section{INTRODUCTION}

The socioeconomic organization of hunter-fisher-gatherer (HFG) peoples varies greatly between different groups. This is true both of groups living on the northern coasts and between these groups and others in the rest of the world. A comparative approach is essential if we are to understand the reasons for such diversity. We undertake such an approach here, using both the archaeological and the anthropological records.

We will argue that the implications of HFG variability on the northern coasts have not been fully integrated into more general discourses on HFGs elsewhere. It is also true that some particular aspects of theory developed elsewhere have only been partially explored with regard to the northern coasts. We will try to point out some of the benefits of crossfertilization. Renouf (1984:18) defined the northern coasts as those in the temperate, Subarctic, and Arctic environmental zones, and we follow that definition here.

\section{ANTHROPOLOGY: THE DEVELOPMENT OF VARIABILITY}

\section{The Nomadic Style}

Since the mid-20th century, archaeology and anthropology have been faced with two conflicting ideas about HFGs. Though these ideas overlap to some extent, their unreconciled differences have been very influential throughout the discipline.

On the one hand, Julian Steward (1955) argued that small mobile bands were the best way for HFGs to exploit areas with scattered and unreliable resources. Such areas occur in various places round the world, and HFGs organized themselves in broadly similar ways in all of them. Steward therefore rejected the "culture area" scenario, in which degree of cultural similarity revealed ancestral relationships: since band-living HFGs in the Great Basin, the Kalahari, and Australia were patently not descended

\footnotetext{
${ }^{1}$ Durham University, Dawson Building, Department of Archaeology, South Road, Durham, DH1 3LE, United Kingdom

${ }^{2}$ Corresponding author: p.a.rowley-conwy@durham.ac.uk

(C) The Arctic Institute of North America
} 
from a common origin, relatedness could not account for the fact that they all lived in bands. What linked them was their similar ecological setting. Economy and society had thus adapted to deal with the similar problems they faced. Steward coined the term "culture core" to cover the aspects most closely linked to economy: these were technology and subsistence, as well as some social arrangements closely linked with subsistence activities. Other social arrangements were less closely linked, while religion was much less closely linked and displayed more variability (Steward, 1955).

On the other hand, Elman R. Service (1962) argued that band society was the most simple and rudimentary form of human society. Service (1962:107-108) saw the global ubiquity of bands as a sign not of adaptation, but of primitiveness, stressing the:

...important, even astonishing, fact that we find this social structure in all major quarters of the earth and in such tremendously varying habitats as deserts, seacoasts, plains, and jungles, in tropical, polar, and temperate zones, with great variations in kinds and amounts of food, and with seasonal and yearly alterations in the supplies. This is an even better reason for thinking that the patrilocal band is early; it seems an almost inevitable kind of organization.

Steward thus took an adaptive view, in which band society was interesting for its own sake. Service in contrast took a progressive view, in which bands were interesting more for what they would change into. Service dealt with variability by ignoring it: his introductory text The Hunters (Service, 1966) explicitly excluded Northwest Coast societies. The definitive volume Man the Hunter reinforced this picture. In the introductory chapter, the editors defined the "Nomadic Style": "We make two basic assumptions about hunters and gatherers: (1) they live in small groups and (2) they move around a lot" (Lee and DeVore, 1968:11). Stemming from this was a low level of personal propertyand thus an egalitarian society; fluid group membership and an absence of territoriality; and an absence of food storage. (We capitalize "Nomadic Style" and other definitional terms introduced below to avoid confusion with the use of these words when not referring to the designated HFG category.)

The Nomadic Style definition ignored even the variability described within Man the Hunter: Suttles (1968) and Watanabe (1968) considered the Northwest Coast and the Ainu respectively, both very different. The Nomadic Style in fact bore an uncanny resemblance to the !Kung as described by Lee in his own chapter later in the book (Lee, 1968). If the Nomadic Style played a disproportionate part in generalizations about hunter-gatherers, the !Kung played a disproportionate part in the generation of the Nomadic Style itself.

The Nomadic Style provided a simple uniformitarian view of what HFGs were like. It was adopted by many archaeologists, perhaps more enthusiastically in Europe, where prehistorians are less exposed to cultural anthropology as students.

\section{Collectors and Delayed Return}

The 1980s saw the dethronement of the normative Nomadic Style. Two major typologies of HFG variability were put forward in the early 1980s. Each of these regarded the Nomadic Style as just one end of the range, the other ends comprising Collectors (Binford, 1980) and Delayed Return societies (Woodburn, 1980, 1982).

Binford (1980) defined the fundamental distinction between Foragers and Collectors. Foragers correspond to the Nomadic Style, which involves high levels of mobility, daily food collection, and no food storage. Apart from the residential base, the only other sites created by Foragers are what Binford termed "locations"-very short-lived extraction sites with little artifactual discard. The Collector category grew from Binford's own observations among the Nunamiut of northern Alaska. Collectors usually move to a new residential base less frequently. They are found in environments with greater spatial and temporal variation in resources. Food storage mitigates temporal variation, while logistic procurement trips mitigate spatial variation. The logistic trips involve task groups that target a particular resource, often using outlying camps and conserving the resource in the field before transporting it back to the base. Three additional site types may thus be found: field camps, lived in by the task group while away from the residential base; stations, which include observation posts, ambush points, and hunting stands; and caches for temporary field storage (Binford, 1980). Simplified models of these strategies are presented in Figure 1.

Woodburn $(1980,1982)$ divided HFG societies into "Immediate Return" and "Delayed Return" types. The Immediate Return type corresponds to the Nomadic Style. Woodburn stressed the flexible nature of their social groups: changeable membership allows people to move to resources, and there is no mechanism such as territoriality whereby any individual can be denied access to resources. Delayed Return groups in contrast are not egalitarian"people hold rights over assets of some sort" (Woodburn, 1982:432), whether food stores, technological facilities such as traps, or female kin who may be bestowed in marriage on other men. This category includes groups like the Northwest Coast and the Ainu (Woodburn, 1980:98).

These classifications are not congruent. The Nomadic Style equates clearly with Binford's Foragers and Woodburn's Immediate Return, but the Collector and Delayed Return categories differ substantially. Binford stressed the logistic transport and storage of food for his Collectors, also part of Woodburn's Delayed Return scenario. Woodburn stressed social hierarchies and territorial lineages, but these played no part in Binford's definition of Collectors. 


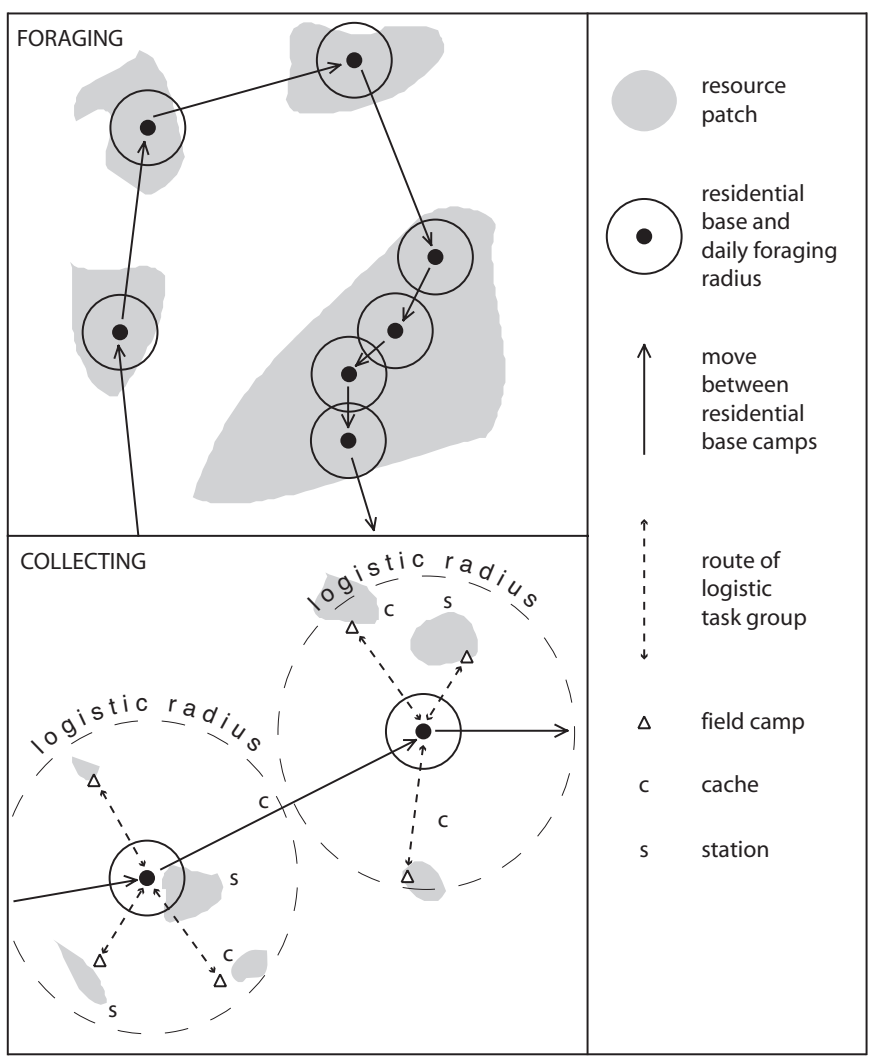

FIG. 1. Schematic maps contrasting Foragers (top) with Collectors (bottom), based on the discussion of Binford (1980).

Woodburn's typology failed to deal very well with two major groups: Australian Aborigines and (more importantly for the northern coasts) Inuit. Woodburn (1982:108) categorized Australian Aborigines as Delayed Return because of their organization into territorial lineages and male control over women, while admitting that their simple technology and lack of food storage were more similar to Immediate Return strategies. Binford did not consider Australian Aborigines directly, but the lack of food transport and storage clearly identify them as Foragers. Woodburn hardly considered the Inuit; they fit very poorly into his system, being egalitarian and non-territorial and yet depending on the transport and storage of food.

It was left to Layton (1986) to tidy up the situation and provide a comprehensive categorization. He resolved the Inuit and Aborigine anomalies by stressing one thing: degree of control over land and its unharvested resources, and in particular, the adaptive aspects of territoriality, storage, and sharing.

Inuit are obliged to store. The Nunamiut, for example, procure $70 \%$ of their annual food supply in 30 days and would not survive without large-scale storage (Binford, 1978). Complex technology is required to achieve this (Torrence, 1983, 2001). Using the theory of territoriality put forward by Dyson-Hudson and Smith (1978), Layton (1986) points out that territorial defence is not viable in an Arctic environment with high spatial and interannual variability in resources. As a result, territorial descent groups are absent and group membership is fluid. Food sharing is widespread, whether shortly after the kill as among Netsilik seal hunters (Balikci, 1970:133-138) and Nunamiut caribou hunters (Gubser, 1965:81-82; Binford, 1978:141-142), or after meat has been stored by individual families, but supplies of some families have run low (Binford, 1978:140).

Layton (1986) also dealt with the Australian Aborigines, pointing out that the territorial lineage and the actual foraging unit are not the same. Membership of foraging bands is flexible, and there is no exclusive control over food resources. The territory claimed by the lineage is restricted to a number of sacred sites, often with a water source but far too small in area to provide all subsistence needs; what is exclusive is the ritual knowledge that pertains to a particular part of the landscape. Ecological factors by themselves do not explain all the differences between the Australian Aborigines and the !Kung (Layton, 1986:28), but the ritual knowledge associated with place in Australia: "...allows people to navigate in the bush: the mental map of criss-crossing tracks left by the heroes, each a string of sacred sites, provides a framework within which to navigate from the few visible hills to invisible water supplies" (Layton, 1986:23).

Thus settlement flexibility and food sharing are what is expected in an environment without much regular seasonal variation, while the exclusive ritual knowledge of the lineage is one way of coping with the sequential drying out of water sources.

The upshot is a four-fold typology of HFGs, expressed by Layton (2005) on a graph (Fig. 2). Where there is not much seasonal variation (the lower part of the graph), groups like the !Kung, Hadza, and Australian Aborigines use simple technologies and consume food immediately. More seasonal variation, as among the Inuit and the Northwest Coast groups, requires more complex technologies to procure temporarily available resources in bulk and preserve them. On the horizontal axis, territoriality is linked to resource predictability and productivity. Towards the left, resource availability is evenly spread through the year (!Kung, Hadza) or concentrated in bursts unpredictable in time and space (Inuit). Territorial defence under either circumstance is unviable, and local descent groups therefore do not control areas of the land. Towards the right, resources occur in predictable bursts that can be harvested and stored (Northwest Coast salmon runs), or in hidden locations whose whereabouts are preserved in ritual knowledge (Australian water). In these areas, property-owning lineages control parts of the land (Layton, 1986, 2005).

Thus (ignoring the Australian Aborigines) both Collectors and Delayed Return groups collect and store food. But only among Delayed Return groups do hierarchical lineages control particular resource points and the stores of food therefrom. 


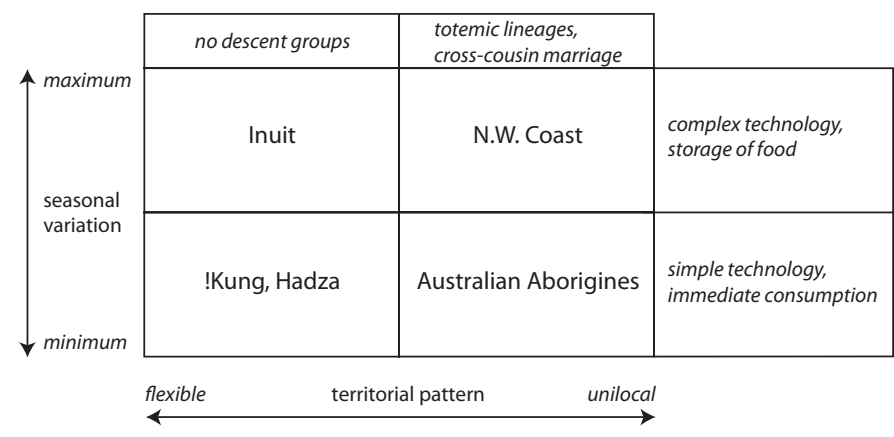

FIG. 2. Typology of hunter-fisher-gatherer peoples, redrawn from Layton (2005: Fig. 7.3).

\section{Variability on the Northern Coasts}

Archaeologists dealing with the northern coasts have quite rightly been wary of adopting "off the peg" models from anthropology, especially dichotomous anthropological ones such as those of Woodburn and Binford described above, or more diffuse archaeological concepts such as "simple" versus "complex" (e.g., Olsen, 1994:20-22; Hood, 1995). Territorial ownership by lineages emerges as of major importance among higher latitude groups in Layton's synthesis (Fig. 2). If territorial ownership is treated as an axis of variation rather than a dichotomous classification, the discussion of variability can be taken further.

We start by considering groups at the extreme ends of the range of variation. The Nootka of Vancouver Island are heavily dependent on maritime resources (Drucker, 1951). The seasonally productive and predictable nature of these resources was the basis for a sophisticated Delayed Return system. The social hierarchy went from chiefs at the top to slaves at the bottom. The lineage headed by each chief was a land-owning unit. The situation of one sub-group, the Kyuquot, is shown in Figure 3. Everyone assembled at an aggregation site for the summer, hunting sea mammals. In autumn each of the 13 lineages moved to the salmon fishing camp it owned, where large quantities of fish were harvested and preserved. At the end of the salmon season these stores were moved to the winter village, where several lineages collected. Major freight canoes could be $11-13 \mathrm{~m}$ long; two could be combined into a raft, using the wall planks from the houses, to transport large quantities of people and goods (Drucker, 1951:83, 88). Drucker (1983:90) suggests that each lineage numbered in the region of $80-200$ people. If so, the 13 lineage camps in Figure 3 would have contained between 1040 and 2600 people-a remarkable density for an area of land so small.

The Netsilik of Pelly Bay provide the antithesis. They were similarly heavily dependent on marine resources and storage (Balikci, 1968, 1970). The movements of the Arviligjuarmiut subgroup in 1919 are plotted in Figure 4. Fish from the rivers was stored and cached, as was caribou meat from the autumn hunt. The caches were revisited during winter and spring, when people were camped on the ice for seal hunting, to supplement the seal meat. Seal

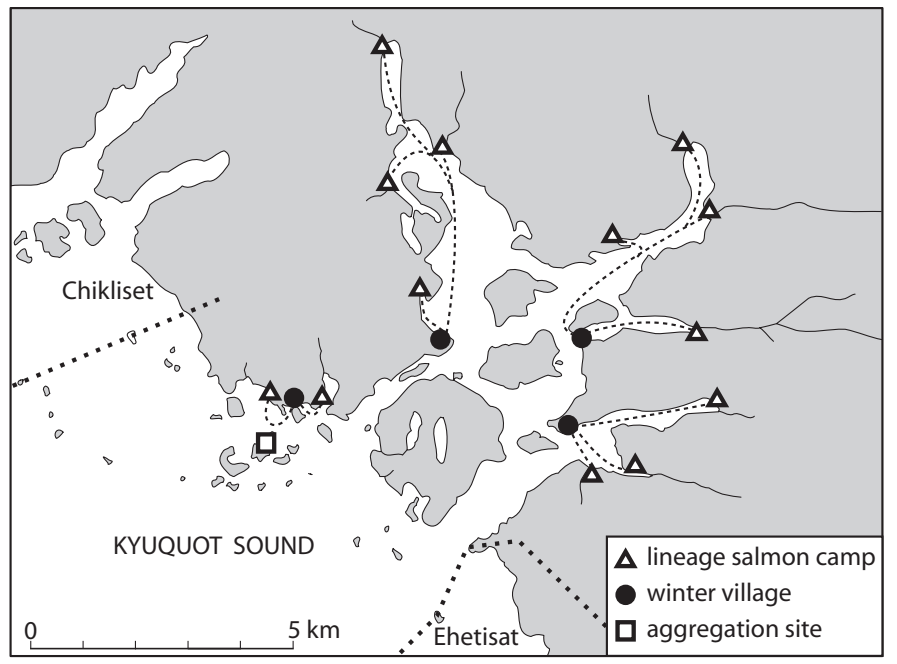

FIG. 3. Settlement patterns of the Kyuquot subgroup of the Nootka, redrawn from Drucker (1951:map 2). Dotted lines join the individual lineage salmon camps with the winter villages they shared.

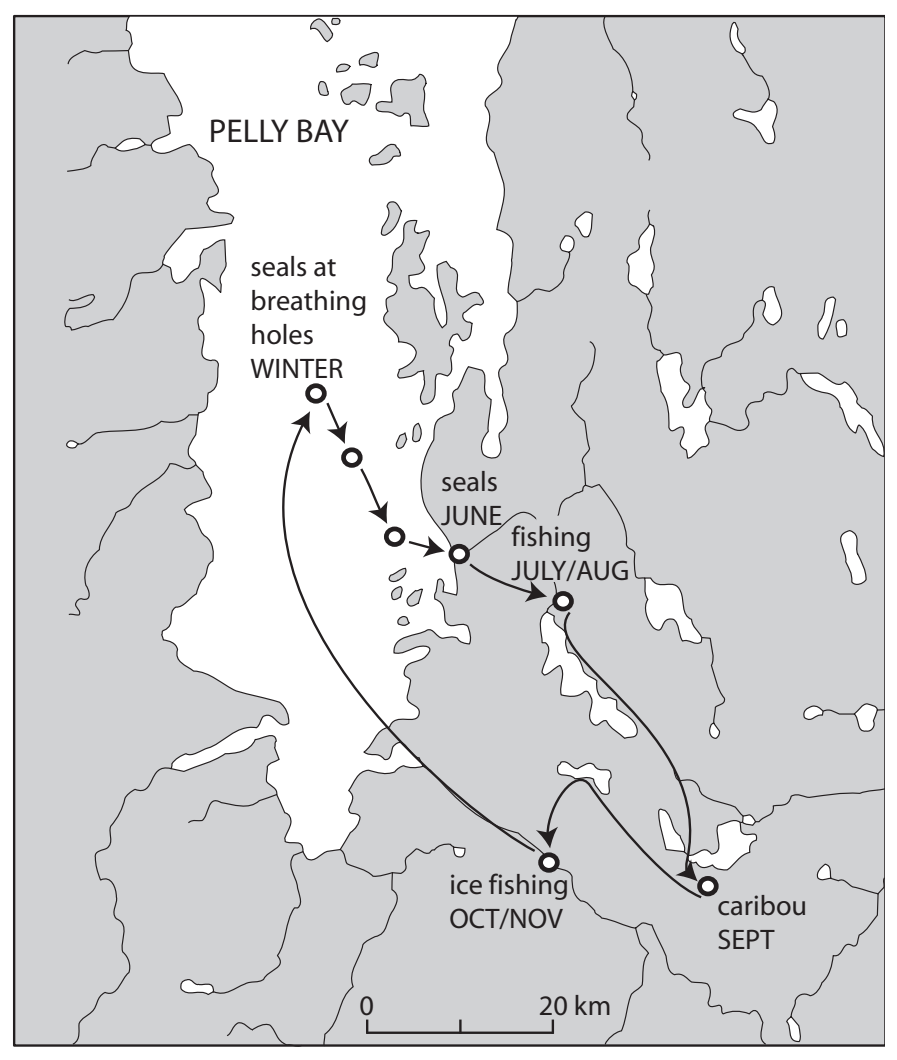

FIG. 4. Settlement pattern of the Arviligjuarmiut subgroup of the Netsilik in 1919, redrawn from Balikci (1968: Fig. 1).

blubber from the spring hunt was preserved for the next winter. Extended families usually cached fish and caribou meat together. No territoriality appears to have existed, and no social hierarchy is evident (Balikci, 1970). The entire Netsilik group, not just the Arviligjuarmiut, numbered 259 people in 1923; around Pelly Bay there were just 54 people (Balikci, 1970:xxiii, 129). Resources were too scattered and unreliable to enable a Delayed Return system to emerge; the Netsilik were classic Collectors. 
The two groups described could hardly be more different, even though both collected, stored, and transported food. To underline that we are considering a range of variation, it is useful to consider a group intermediate between them: the Twana, a subgroup of the Coast Salish. Like the Nootka and the Netsilik, the Twana were heavily dependent on the storage of marine resources. Elmendorf and Kroeber (1960) state that for six to eight months of the year, people lived in dispersed campsites practicing a variety of subsistence activities. At this time there was no territoriality, and people from any winter village were free to intermingle, camp, and fish anywhere. In the fall, the salmon arrived. Villages owned particular fish traps, and individual men owned fishing places on these. Much food went into storage in the winter village, and the winter village operated as a territorial unit. The social hierarchy was well developed, and each winter village had a chief. From Elmendorf's map and list of place names (Elmendorf and Kroeber, 1960:32-55) one can gain an impression of the settlement pattern (Fig. 5). Only on the Skokomish River did a group have more than one winter village. Elmendorf (1993:xxix) estimates the total population in 1800 as some 2600, divided up between the winter villages as shown in Figure 5. The Twana therefore display the attributes of Delayed Return, but for part of the year only.

In these three examples territorial ownership by particular lineages is, with the attendant social hierarchy, the major social variable. The range between Collectors and Delayed Return emerges clearly. Variation throughout this range has been persuasively argued by Richardson (1982) to follow the quantity and reliability of resources. Figure 6 plots the degree of lineage ownership of resources on a north-south axis on the west coast of North America, from California to the Arctic, developed from the chart in Richardson (1982: Fig. 2). Resource availability is greatest in the Coast Salish region. Storage of the productive and reliable salmon is vital for winter survival, but marine resources are productive enough during summer for lineage-based territoriality to be relaxed in this season (the Twana are in this group). To the north, resource points become less frequent but remain productive and reliable; territorial ownership therefore becomes more pronounced among the Nootka, culminating in the classic northern Northwest Coast groups: Tsimshian, Tlingit, and Haida. As resource reliability then starts to decline, the Aleut place less emphasis on the ownership of resource points, and the Inuit, little or none (Richardson, 1982).

Richardson's scheme is very effective in calibrating social structure against resource reliability and productivity. It provides a good starting point for the next section, in which we consider HFG variability in the archaeological record.

\section{ARCHAEOLOGY: THE CHALLENGE OF VARIABILITY}

We contend that there has been something of a disjuncture between work on the northern (particularly the Subarctic and Arctic) coasts and much work on HFG archaeology elsewhere. There are two main reasons for this. First, most of the theoretical developments discussed above resulted from the study of subtropical savanna-zone HFGs such as the !Kung, Hadza, and Australian Aborigines. Only the category of Collectors (Binford, 1980) emerged from work in the Arctic. All too often the impression grows from this fact that northern coastal HFGs are "different." Second, northern coastal HFGs are of course just that: coastal. Normative models of HFG behaviour (e.g., Fig. 1) are much easier to construct for terrestrial groups, and even the Arctic Nunamiut are an inland group. Null hypotheses are usually based on human walking speeds and circular distributions of material. Thus while for example Kelly (1995:111 - 160) and Binford (2001) do consider aquatic mobility, most of their discussions are based on interior groups. Specific considerations of aquatic mobility, such as that by Ames (2002), are less common. Raw material frequencies are assumed to decrease uniformly with distance from the source unless some factor counteracts this trend (Renfrew, 1977). However, the pattern of northern coastal groups, living as they do on irregular coastlines and offshore islands and moving about them and carrying raw materials in boats, conflicts with these null hypotheses from the start. The result has been that northern HFGs are often considered a category apart.

\section{Territoriality, Cemeteries, and the Saxe-Goldstein Hypothesis}

Territorial ownership by lineages has emerged as the most crucial social aspect of Delayed Return groups and is the major feature that distinguishes them from Collectors. Few archaeologists have considered territoriality among HFGs on the Subarctic and Arctic coasts; however, a major exception is the discussion of Varanger Fjord by Hodgetts (1999) based on the markedly different frequencies of dolphin and ringed seal in the various houses at the settlement of Gressbakken Nedre Vest. Since some houses have many while others have very few, this pattern does suggest differential access to these resources.

Another approach with potentially wide application involves the treatment of the dead. Saxe (1970:119) defined his hypothesis 8:

Hypothesis \#8: to the degree that corporate group rights to use and/or control crucial but restricted resources are attained and/or legitimized by means of lineal descent from the dead (i.e., lineal claims to ancestors), such groups will maintain formal disposal areas for the exclusive disposal of their dead, and conversely. 


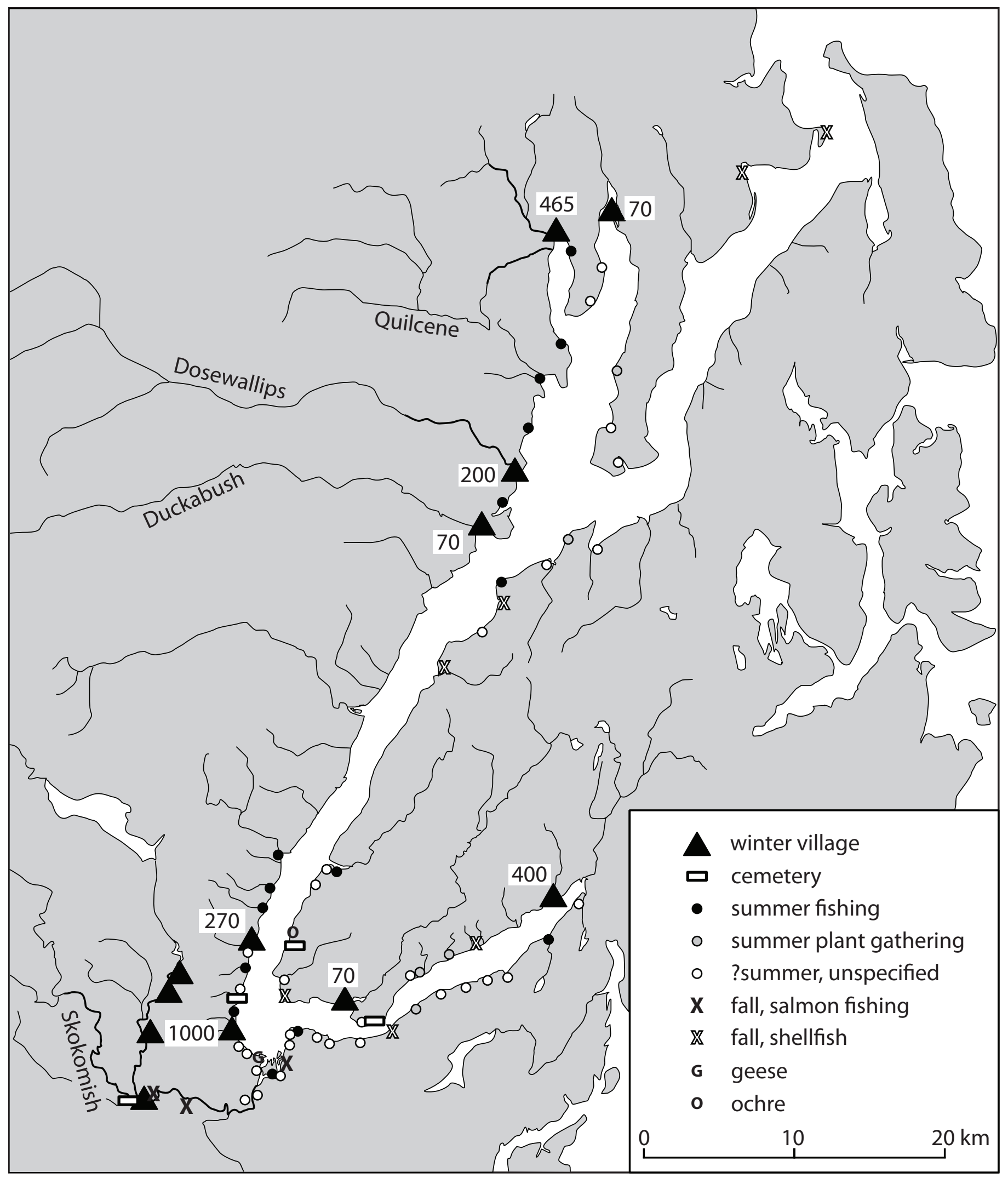

FIG. 5. Settlement pattern of the Twana, based on Elmendorf's list and map (Elmendorf and Kroeber, [1960] 1992:32-55, map between pages 48 and 49). Population estimates for AD 1800 next to each winter village calculated from Elmendorf (1993:xxix). Estimates are based on his statement that the population in 1800 would have been c. $33 \%$ greater than that recorded in 1850. 


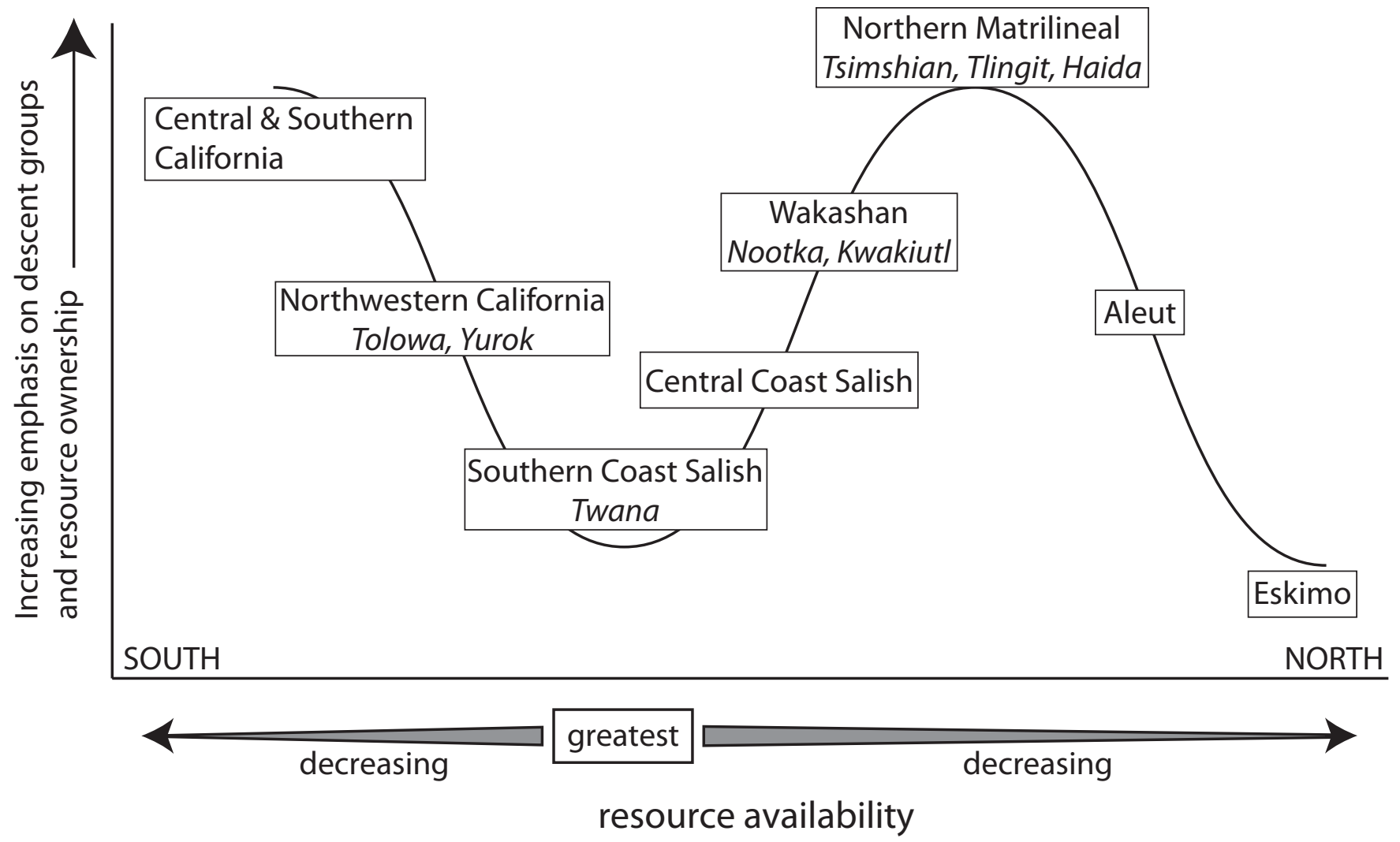

FIG. 6. Graph correlating degree of resource ownership by descent groups and latitudinal variation in resources. Based on Richardson (1982: Fig. 2).

Formal disposal of the dead thus characterizes territorial lineages of the kind found in Delayed Return societies (see above). The corporate local group is in effect using the presence of its ancestors in a cemetery to justify its occupation of a particular area of landscape. Goldstein (1981) tested Saxe's hypothesis against a large body of ethnographic instances, demonstrating that the correlation worked in only one direction: the presence of a cemetery indicates the presence of a unilineal descent group, but the absence of a cemetery does not necessarily mean that such a group did not exist. The group may legitimize its occupation by other means.

This theory has come to be known as the Saxe-Goldstein hypothesis. Keeley (1991) demonstrated a major divide between (1) HFGs in stable resource areas, with greater sedentism and higher population density; and (2) those in areas of less predictable resources, with greater mobility and lower population density (Keeley, 1991: Fig. 17.1). Only those in Group 1 have corporate lineages (Keeley, 1991: Fig. 17.6). The Saxe-Goldstein hypothesis suggests that only Group 1 societies will create cemeteries, though as mentioned, Goldstein (1981) shows that not all of them will do so.

The Saxe-Goldstein hypothesis has been applied to the archaeological record in various parts of the world. Pardoe (1988) considered the Late Pleistocene and Holocene cemeteries along the Murray River in Australia. The river zone has rich and relatively stable resources, while in the surrounding scrubland they are unpredictable and scattered. Population density along the river was probably 20-40 times that of the surrounding area. Cemeteries are found only along the river, and Pardoe (1988) argues that this indicates the presence of territorial lineages. Chattopadhyaya (1996) argues similarly about the cemeteries on the River Ganges in India. Likewise Elder (2010) concludes that Late Mesolithic cemeteries in southern Scandinavia indicate a stable territorial regime.

These archaeological cemeteries all occur where the Saxe-Goldstein hypothesis predicts: where resources are stable and predictable. We therefore believe that the SaxeGoldstein hypothesis, used with due circumspection, provides a useful tool for seeking territorial lineage groups on the northern coasts.

Archaeological cemeteries appear and also disappear in the record. The disappearance of cemeteries in a particular culture might be due to a decrease in resource reliabilitywhich would be difficult to detect archaeologically if the resource spectrum remained unchanged - or alternatively, to a change in the symbolic practices of the culture, for example, choosing to legitimize territoriality by some means other than a cemetery.

One implication of the Saxe-Goldstein hypothesis is that even if HFGs are partially sedentary but do not claim territorial rights, they will not practice formal deposition. Some Inuit groups in North Alaska achieved a degree of permanence on the basis of marine resources, although population was fluid depending on circumstances, and no lineages exercised territorial rights (Spencer, 1959). The non-formal methods of disposal of the dead make strange 
reading to modern sensibilities. Ray (1885, in Murdoch, [1892] 1988:xcvi) described the situation in the 1880s:

The dead are carried out and laid out on the tundra without any ceremony other than the near relatives following the body to its last resting place.... With but few exceptions I never knew them to pay any attention to their dead after they were carried out.... The bodies are usually eaten by the dogs, especially in the winter, and it is no uncommon site to see them gnawing the bones on the roofs of the iglus.

Describing the same period, Murdoch ([1892] 1988:424) states that:

The bodies are laid out upon the ground without any regular arrangement apparently, though it is difficult to be sure of this, as most of the remains have been broken up and scattered by dogs and foxes.

By 1880 , rudimentary grave boxes had recently come into use round Norton Sound, but on Kotzebue Sound "the Malemut still throw out many of their dead" (Nelson, [1899] 1983:312). At Razbinsky on the lower Yukon, the graveyard was just behind the village and became so offensive in summer that it was impossible to camp near it (Nelson, [1899] 1983:247).

These decidedly casual disposal practices would leave no trace in the archaeological record. Alaskan mortuary behaviour has not always been so casual: there are hundreds of burials at Ipiutak, many in log coffins containing elaborate grave goods (Larsen and Rainey, 1948). Could these burials represent a major Delayed Return society? The site remains unique; might resources have been unusually productive and reliable for the relevant period? This was certainly the case in Late Mesolithic southern Scandinavia, with cemeteries such as Skateholm (Larsson, 1989) and Vedbæk (Albrethsen and Brinch Petersen, 1976), which have been argued to reflect territorial lineages (Elder, 2010; Rowley-Conwy, 1998). Cemeteries on the other side of the Atlantic could be considered in the same way. Port au Choix (Tuck, 1976) contains 93 individuals, and there are two other areas of burials and a field camp for mortuary activities (Renouf and Bell, 2011). Rattlers Bight in Labrador has nine burial features (Fitzhugh, 2006:58-63). Farther south, Cow Point in New Brunswick has 60 (Sanger, 1973). In all, there are 40 formal cemeteries from Maine and New Brunswick, just five being known from the rest of New England (Robinson, 2006). This hotspot in the Gulf of Maine suggests an area of Maritime Archaic Delayed Return, an avenue of examination that would repay further study.

Discussion of the Saxe-Goldstein hypothesis has usually focused just on cemeteries, but there are other types of formal disposal of the dead. Stone burial mounds occur well to the north on both sides of the Atlantic. There are two at Ballybrack, Labrador, dating from the earliest

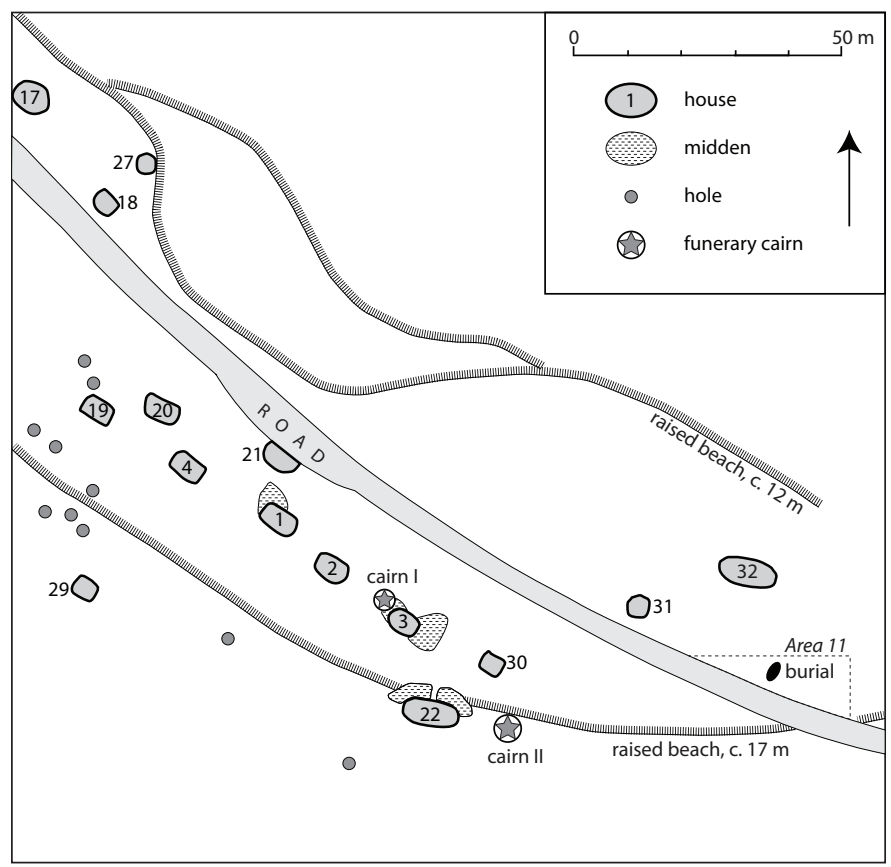

FIG. 7. Plan of the southeastern part of Nyelv Nedre Vest, showing the houses, cooking pits, burial mounds, and the location of Renouf's Area 11 with its burial. This map is combined from Simonsen (1961:opposite p. 397) and Renouf (1989:66, Fig. 2). The two plans do not agree very closely so this should just be treated as a very approximate sketchplan.

phase of the Labrador Maritime Archaic (Fitzhugh, 1978), and the major example at L'Anse Amour is similarly early (Tuck and McGhee, 1976). In the Varanger Fjord, there are three burial cairns at Nyelv Nedre Vest; there are more on other sites, and at Barsnjarga a group of them forms a cairn cemetery separate from any settlement (Simonsen, 1959:6). Like the ones at Ballybrack, the Nyelv Nedre Vest cairns are sited prominently in the landscape, on a raised beach overlooking the sea. Renouf (1989) excavated a flat burial just below two of them. Figure 7 plots this location in relation to the nearby houses and cairns. Other Varanger Fjord sites have the bones of dismembered individuals scattered outside the entrances to the houses (Torgersen et al., 1959). It remains to be demonstrated that all these forms of corpse disposal are contemporary, but the multiplicity of forms calls to mind those of the Aleut: some people were buried in compartments off houses, others in caves, sometimes in canoes or boxes, while chiefs were embalmed (Lantis, 1970:214-217).

The Varanger Fjord cairns have apparently not been discussed with regard to territoriality except for a mention by Olsen (1994:80). But territoriality has been considered for cairns associated with the "megastructures" of the Bothnian coast of Finland. These major stone enclosures have rubble walls up to $1.5 \mathrm{~m}$ high and may measure $60 \mathrm{~m}$ in length. They date from $4000-2000 \mathrm{BC}$, when the coast was uniquely productive (Núñez, 2009). They are in settlements containing houses and cairns, but have no internal features themselves. The site of Kastelli is shown in Figure 8. Bone is not preserved, but some features suggest the cairns 


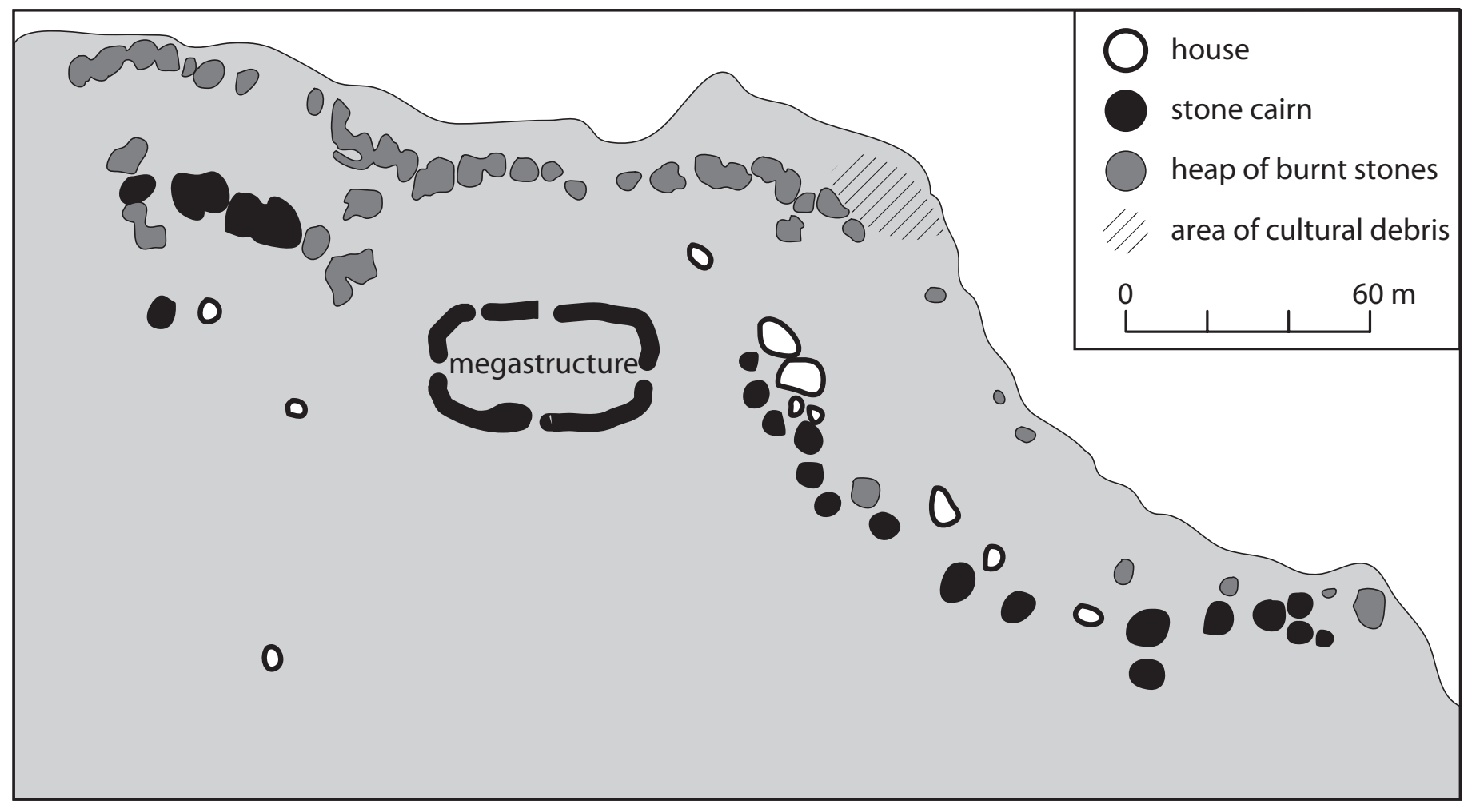

FIG. 8. Plan of the Kastelli settlement in Finland, showing the numerous cairns and the contemporary seashore, redrawn from Núñez (2009: Fig. 3).

were funerary and may have been territorial markers (Núñez and Okkonen, 2005:31). Cairn burials clearly differ from cemeteries of flat graves, but their elaboration and prominence suggests that, like cemeteries, they should be approached using the Saxe-Goldstein hypothesis.

\section{Boats, Colonization, and Mobility}

It is axiomatic that the HFGs of the northern coasts made great use of boats. There are no physical traces of Early Holocene boats. However, the early spread of people up the Atlantic coast of Sweden and Norway and the occupation of offshore islands testify to the existence of boats of some kind (Bjerck, 2008b, 2016; Schmitt et al., 2009; Bjerck and Zangrando, 2013), though their precise nature remains controversial (Glørstad, 2013; Schmitt, 2013). Similar evidence comes from the earliest occupation of the Baltic coast of Sweden (Petterson and Wikell, 2014). The coastal focus of the earliest occupation of Labrador also clearly testifies to the presence of boats (Fitzhugh, 1978, 2006). The regular killing of large pelagic species such as killer whale (at Lystrup in Denmark: Enghoff, 2011), whitebeaked dolphin (at Huseby Klev in Sweden: Hernek and Nordqvist, 1995), and swordfish (in the Gulf of Maine: Sanger, 2010; Bourque, 2012) could not have been carried out without boats. Long sea voyages are attested by the occupation of the Madeleine Islands, more than $80 \mathrm{~km}$ out in the Gulf of St. Lawrence (Dumais and Rousseau, 1986), and by stone raw materials crossing the Gulf of Maine to Nova Scotia (Sanger, 1991).
Various canoe voyages, ethnographic and experimental, are listed in Table 1. Compared to walking speed, the distances that can be covered are enormous. Ames (2002:36) suggests that $15-30 \mathrm{~km}$ would be an easy daily foraging radius, with $60 \mathrm{~km}$ for a one-way trip. Table 1 shows that this should be achievable at least by birchbark canoes, though dugouts may be more limited. Logistic transport is massively facilitated: "weights that are daunting on foot are trivial in many boats: what is $15 \mathrm{~kg}$ in a boat that can easily carry $2000 \mathrm{~kg}$ ?" (Ames, 2002:39). These are the very features that have led to northern coastal HFGs falling outside the normative models of HFGs put forward for lower-latitude terrestrial groups.

Colonization northward up the seacoasts appears to have been rapid on both sides of the Atlantic. In Norway, the west coast was deglaciated several millennia before humans arrived. Although this delay has sometimes been attributed to cultural factors (Bjerck, 2009:119), it has recently been argued that a major glacier around Oslo Fjord blocked the way, and people moved in during the early postglacial period as soon as this glacier melted (Glørstad, 2014). Colonization of the whole coast took just 200-300 years (Bjerck, 2008a). In Labrador, colonization was also blocked by ice until well into the postglacial (Clark and Fitzhugh, 1990). A key point is that colonization was not just a rapid event followed by stasis and regionalization. In both cases, the archaeological record testifies to continued voyaging along the coasts after the initial colonization. In Norway, the earlier Mesolithic was culturally fairly uniform along most of the coasts except for the area of the Early Stone Age 
TABLE 1. Speeds and distances attained by specific ethnographic and experimental canoe voyages. For the purposes of the calculations, one day is assumed to involve eight hours of sailing.

\begin{tabular}{|c|c|c|c|c|c|}
\hline Vessel type & Distance $(\mathrm{km})$ & Time (h) & Speed $(\mathrm{km} / \mathrm{h})$ & Notes & Reference \\
\hline \multicolumn{6}{|l|}{ Ethnographic: } \\
\hline Dugout - cedar & 64 & "one day" & $8 ?$ & & Sproat, in Ames, 2002:30 \\
\hline Dugout - cedar & 145 & 21 & 6.9 & with wind & Eells, in Ames, 2002:30 \\
\hline Dugout - cedar & 145 & 33 & 4.4 & & Eells, in Ames, 2002:30 \\
\hline Dugout - cedar & 145 & 31 & 4.7 & & Eells, in Ames, 2002:30 \\
\hline Dugout - cedar & 145 & 23 & 6.3 & with wind & Eells, in Ames, 2002:30 \\
\hline Dugout - cedar & 30 & 11 & 2.7 & into gale & Kane, in Durham, 1960:77 \\
\hline Birchbark & 80 & "one day" & $10 ?$ & average & Adney and Chapelle, 1983:145 \\
\hline Birchbark & $120-130$ & "one day" & $12-13 ?$ & exceptional & Adney and Chapelle, 1983:145 \\
\hline Birchbark & $55-74$ & "one day" & $7-9 ?$ & & Marshall, 1986:32 \\
\hline Birchbark & 80 & "one day" & $10 ?$ & sea crossing & Speck, 1922:119 \\
\hline Umiak & 150 & "two days" & $9 ?$ & sea crossing & Petersen, 1986:165 \\
\hline Umiak & 40 & "one day" & $5 ?$ & lake & Grønnow et al., 1983:24 \\
\hline \multicolumn{6}{|c|}{ Experimental/replicative: } \\
\hline Dugout - lime & 17 & 5 & 3.3 & sea crossing & Christensen, 1997:288-289 \\
\hline Dugout - lime & 15 & 5 & 3 & sea crossing & Christensen et al., 1979:94 \\
\hline Dugout - poplar & 28 & 5 & 5.6 & outrigger, sail & Österholm, 1997:169 \\
\hline Dugout - poplar & 50 & 11 & 4.5 & outrigger & Österholm, 1997:170 \\
\hline Dugout - not stated & 206 & 63.5 & 3.2 & 10 sea crossings & Tichy, 1999:203 \\
\hline Dugout - oak & 603 & 161.8 & 3.7 & 36 sea crossings & Tichy, 1999:203-204 \\
\hline Birchbark & 110 & 10 & 11 & sea crossing & Cook, 2007:55 \\
\hline
\end{tabular}

or Komsa culture in the far north (Bjerck, 2008a:101-102; Glørstad, 2013:65). Bjerck (2007:19) argued that this uniformity was caused by high human mobility, which decreased in later periods (Bjerck, 1990; Bergsvik, 2001). In Labrador, distinctive Ramah Bay chert dating from the time when colonization reached its source has been found in deposits far to the south (Fitzhugh, 2006), which also suggests high mobility.

Continuous voyaging of this kind was necessary for demographic reasons. A small colonizing group would not number enough people to be reproductively viable in the long term. Moore (2001) presents various simulations showing that groups numbering below 100 are unlikely to survive in isolation. Many of the members of such a group are likely to be closely related to each other, so that the incest prohibition reduces mate availability. Stochastic variation in the sex of children born will further reduce it. Even a group of 100 people reduced in population in $50 \%$ of Moore's simulations; only when such a group exchanged mates with another group of the same size, thus increasing the breeding pool to 200 people, did population increase in $90 \%$ of cases (Moore, 2001: Table 8). When settlements are arranged in a line, for example along a coastline, extensive traveling between settlements would be necessary to ensure demographic survival. This traveling is what accounts for Norwegian Early Mesolithic cultural uniformity and the wide spread of Ramah chert. One study has argued that colonizing societies are often matrilineal (Keegan, 2010): women formed the residential core, while in-marrying males needed to keep touch with their own social group and return frequently. "The mobility of disenfranchised males promoted trading, raiding, and the exploration of new territories" (Keegan, 2010:176).

The use of boats and the likely continuous nature of travel and contact between bands is an area of research in which the archaeologists of the northern coasts have led the way, but which has yet to be fully explored for other regions. All small human groups will face the demographic problems touched on above. Boat travel is a way of hugely enhancing both distance and payload. We suspect that canoes are often a highly underrated aspect of HFG technology, even in interior regions where movement would be on rivers or lakes. There are, of course, groups in areas where lack of such waterways means that boats are ruled out - and here we reiterate the over-emphasis given to HFGs occupying semi-desert areas in the construction of our general models of HFGs. A major lesson from the northern coasts is that boating technology, even though not directly visible in the archaeological record, is likely to have been far more sophisticated than we have tended to believe. The earliest penetration of the mid-continental zones of the Americas may have been facilitated by boat. Colonizers moving north across Europe as the glaciers retreated might have moved by boat along rivers, not on foot. Tromnau (1987) has suggested that curiously worked pieces of reindeer antler from Late Palaeolithic Stellmoor in northern Germany might have been elements of frames of skin boats; the site was on a lake across which the deer probably swam, so interception by boat would have facilitated hunting (Bratlund, 1991). If the late glacial hunters were adept in the use of boats and were not just pedestrian HFGs, this would explain why they were able to colonize the skerries of the West Swedish coast at that time (Schmitt and Svedhage, 2016).

\section{CONCLUSIONS}

This discussion of the HFGs of the northern coasts has identified some ways in which these people have been 
cast as different from many of the groups upon which our standard models are based. Boats, transport, and longdistance logistic movement along convoluted coastlines and offshore islands are the major factors that have led to this difference in perspective.

One result is that some aspects of HFG theory from more southern areas have not been exploited as fully as they might with regard to the northern coasts. We have highlighted the possibility of high-latitude Delayed Return groups and suggested the use of the Saxe-Goldstein hypothesis as a way to detect such groups. Similarly, studies of more southerly groups would do well to consider a key element in the archaeology of northern HFGs, namely the ubiquity of boats and canoes: boats can access a variety of waterways and solve a lot of logistic problems, and often this possibility is not given due consideration. If this contribution results in these ideas becoming more widely applied to different areas, it has served its purpose.

\section{REFERENCES}

Adney, E.T., and Chapelle, H.I. 1983. The bark canoes and skin boats of North America. U.S. National Museum Bulletin 230. Washington, D.C.: Smithsonian Institution Press.

Albrethsen, S.E., and Brinch Petersen, E. 1976. Excavations of a Mesolithic cemetery at Vedbæk, Denmark. Acta Archaeologica 47:1-28.

Ames, K.M. 2002. Going by boat: The forager-collector continuum at sea. In: Fitzhugh, B., and Habu, J., eds. Beyond foraging and collecting: Evolutionary change in hunter-gatherer settlement systems. New York: Kluwer. 19-52.

Balikci, A. 1968. The Netsilik Eskimos: Adaptive processes. In: Lee, R.B., and DeVore, I., eds. Man the hunter. Chicago: Aldine. 78-82.

—. 1970. The Netsilik Eskimo. New York: Natural History Press.

Bergsvik, K.A. 2001. Sedentary and mobile hunter-fishers in Stone Age western Norway. Arctic Anthropology 38(1):2-26.

Binford, L.R. 1978. Nunamiut ethnoarchaeology. New York: Academic Press.

- 1980. Willow smoke and dogs' tails: Hunter-gatherer settlement systems and archaeological site formation. American Antiquity 45(1):4-20. https://doi.org/10.2307/279653

- 2001. Constructing frames of reference: An analytical method for archaeological theory building using ethnographic and environmental datasets. Berkeley: University of California Press.

Bjerck, H.B. 1990. Mesolithic site types and settlement patterns at Vega, northern Norway. Acta Archaeologica 60:1-32.

. 2007. Mesolithic coastal settlements and shell middens (?) in Norway. In: Milner, N., Craig, O.E., and Bailey, G.N., eds. Shell middens in Atlantic Europe. Oxford: Oxbow Books. $5-30$. 2008a. Norwegian Mesolithic trends: A review. In: Bailey, G., and Spikins, P., eds. Mesolithic Europe. Cambridge: Cambridge University Press. 60-106.

—. 2008b. Tidligmesolittisk tid (TM) og Fosnatradisjon 9500-8000 BC [The Early Mesolithic period and Fosna Tradition 9500-8000 BC]. In: Bjerck, H.B., ed. Ormen Lange Nyhamna. Trondheim: Tapir. 552-570.

- 2009. Colonizing seascapes: Comparative perspectives on the development of maritime relations in Scandinavia and Patagonia. Arctic Anthropology 46(1-2):118-131.

https://doi.org/10.1353/arc.0.0019

- 2016. Settlements and seafaring: Reflections on the integration of boats and settlements among marine foragers in Early Mesolithic Norway and the Yámana of Tierra del Fuego. Journal of Island and Coastal Archaeology.

https://doi.org/10.1080/15564894.2016.1190425

Bjerck, H.B., and Zangrando, A.F. 2013. Marine ventures: Comparative perspectives on the dynamics of early human approaches to the seascapes of Tierra del Fuego and Norway. Journal of Island and Coastal Archaeology 8(1):79-90. https://doi.org/10.1080/15564894.2012.756083

Bourque, B. 2012. The Swordfish hunters: The history and ecology of an ancient American sea people. Piermont, New York: Bunker Hill Publishing Inc.

Bratlund, B. 1991. A study of hunting lesions containing flint fragments on reindeer bones at Stellmoor, Schleswig-Holstein, Germany. In: Barton, N., Roberts, A.J., and Roe, D.A., eds. The Late Glacial in Northwest Europe: Human adaptation and environmental change at the end of the Pleistocene. CBA Research Report No. 77. London: Council for British Archaeology. 193-207.

Chattopadhyaya, U.C. 1996. Settlement pattern and the spatial organization of subsistence and mortuary practices in the Mesolithic Ganges Valley, north-central India. World Archaeology 27(3):461 - 476. https://doi.org/10.1080/00438243.1996.9980320

Christensen, C. 1997. Boats and navigation in the Stone Age. In: Pedersen, L., Fischer, A., and Aaby, B., eds. The Danish Storebælt since the Ice Age: Man, sea and forest. Copenhagen: A/S Storebælt Fixed Link. 282-289.

Christensen, C., Grønnow, B., Hansen, C.V., Jønsson, J.H., Malmros, C., and Petersen, P.V. 1979. Stammebåden. Et eksperiment med udhugning og sejlads [Dugouts: An experiment with hollowing out and sailing]. Nationalmuseets Arbejdsmark 1979:89-94.

Clark, P.U., and Fitzhugh, W.W. 1990. Late deglaciation of the central Labrador coast and its implications for the age of glacial lakes Naskaupi and McLean and for prehistory. Quaternary Research 34(3):296-305. https://doi.org/10.1016/0033-5894(90)90042-J

Cook, D.S. 2007. Above the gravel bar: The Native canoe routes of Maine, 3rd ed. Solon, Maine: Polar Bear \& Co.

Drucker, P. 1951. The northern and central Nootkan tribes. Smithsonian Institution, Bureau of American Ethnology Bulletin 144. Washington, D.C.: U.S. Government Printing Office. 
1983. Ecology and political organization on the Northwest Coast of North America. In: Tooker, E., ed. The development of political organization in Native North America. Washington, D.C.: American Ethnological Society. 86-96.

Dumais, P., and Rousseau, G. 1986. Menagoesenog ou les Îles de la Madeleine: contexte environmentale. In: Martijn, C.A., ed. Les Micmacs et la Mer. Quebec: Société Recherches Amérindiennes du Québec. 67-97.

Durham, B. 1960. Canoes and kayaks of western America. Seattle, Washington: Copper Canoe Press.

Dyson-Hudson, R., and Smith, E.A. 1978. Human territoriality: An ecological reassessment. American Anthropologist 80(1):21-41. https://doi.org/10.1525/aa.1978.80.1.02a00020

Elder, E. 2010. A comparison of the Late Pleistocene and Early Holocene burials of North Africa and western Europe. Grim investigations: Reaping the dead. British Archaeological Reports International Series 2143. Oxford: Archaeopress.

Elmendorf, W.W. 1993. Twana narratives: Native historical accounts of a Coast Salish culture. Seattle: University of Washington Press.

Elmendorf, W.W., and Kroeber, A.L. (1960) 1992. The structure of Twana culture with comparative notes on the structure of Yurok culture. Research Studies, Monographic Supplement 2, reprint. Pullman: Washington State University.

Enghoff, I.B. 2011. Regionality and biotope exploitation in Danish Ertebølle and adjoining periods. Scientia Danica Series B, Biologica I. Copenhagen: Det Kongelige Danske Videnskabernes Selskab.

Fitzhugh, W.W. 1978. Maritime Archaic cultures of the central and northern Labrador coast. Arctic Anthropology 15(2):61 - 95.

- 2006. Settlement, social and ceremonial change in the Labrador Maritime Archaic. In: Sanger, D., and Renouf, M.A.P., eds. The Archaic of the Far Northeast. Orono: University of Maine Press. 47-81.

Glørstad, H. 2013. Where are the missing boats? The pioneer settlement of Norway as long-term history. Norwegian Archaeological Review 46(1):57-80.

https://doi.org/10.1080/00293652.2013.777095

. 2014. Deglaciation, sea-level change and the Holocene colonization of Norway. In: Harff, J., Bailey, G., and Lüth, F., eds. Geology and archaeology: Submerged landscapes of the continental shelf. Special Publications No. 411. London: Geological Society. 9-25.

https://oi.org/10.1144/SP411.7

Goldstein, L. 1981. One-dimensional archaeology and multidimensional people: Spatial organisation and mortuary analysis. In: Chapman, R., Kinnes, I., and Randsborg, K., eds. The archaeology of death. Cambridge: Cambridge University Press. 53-69.

Grønnow, B., Meldgaard, M., and Nielsen, J.B. 1983. Aasivissuit the great summer camp: Archaeological, ethnographical and zoo-archaeological studies of a caribou-hunting site in West Greenland. Meddelelser om Grønland, Man \& Society 5.

Gubser, N.J. 1965. The Nunamiut Eskimos: Hunters of caribou. New Haven: Yale University Press.
Hernek, R., and Nordqvist, B. 1995. Världens äldsta Tuggummi? The world's oldest chewing gum?] Stockholm: Riksantikvarieämbetet.

Hodgetts, L. 1999. Animal bones and human society in the late Younger Stone Age of Arctic Norway, 2 vols. PhD thesis, Department of Archaeology, Durham University, Durham, United Kingdom.

Hood, B.C. 1995. Circumpolar comparison revisited: Huntergatherer complexity in the North Norwegian Stone Age and the Labrador Maritime Archaic. Arctic Anthropology 32(2):75- 105 .

Keegan, W.F. 2010. Demographic imperatives for island colonists. In: Anderson, A., Barrett, J.H., and Boyle, K.V., eds. Global origins and development of seafaring. Cambridge: McDonald Institute for Archaeological Research. 171-178.

Keeley, L.H. 1991. Ethnographic models for late glacial huntergatherers. In: Barton, N., Roberts, A.J., and Roe, D.A., eds. The Late Glacial in Northwest Europe. CBA Research Report 77. London: Council for British Archaeology. 179-190.

Kelly, R.L. 1995. The foraging spectrum: Diversity in huntergatherer lifeways. Washington, D.C.: Smithsonian Institution Press.

Lantis, M. 1970. The Aleut social system, 1750 to 1810 , from early historical sources. In: Lantis, M., ed. Ethnohistory in southwestern Alaska and the southern Yukon: Method and content. Lexington: University Press of Kentucky. 139-301.

Larsen, H., and Rainey, F. 1948. Ipiutak and the Arctic Whale Hunting Culture. Anthropological Papers of the American Museum of Natural History 42. New York: AMNH.

Larsson, L. 1989. Late Mesolithic settlements and cemeteries at Skateholm, southern Sweden. In: Bonsall, C., ed. The Mesolithic in Europe. Edinburgh: John Donald. 367-378.

Layton, R. 1986. Political and territorial structures among huntergatherers. Man (N.S.) 21(1):18-33. https://doi.org/10.2307/2802644

- 2005. Are immediate-return strategies adaptive? In: Widlok, T., and Tadesse, W.G., eds. Property and equality, Vol. 1: Ritualisation, sharing, egalitarianism. Oxford: Berghahn. $130-150$.

Lee, R.B. 1968. What hunters do for a living, or, how to make out on scarce resources. In: Lee, R.B., and DeVore, I., eds. Man the hunter. Chicago: Aldine. 30-48.

Lee, R.B., and DeVore, I. 1968. Problems in the study of hunters and gatherers. In: Lee, R.B., and DeVore, I., eds. Man the hunter. Chicago: Aldine. 3-12.

Marshall, I. 1986. Le canot de haute mer des Micmacs. In: Martijn, C.A., ed. Les Micmacs et la mer. Quebec: Société Recherches Amérindiennes du Québec. 29-47.

Moore, J.H. 2001. Evaluating five models of human colonization. American Anthropologist 103(2):395-408.

https://doi.org/10.1525/aa.2001.103.2.395

Murdoch, J. (1892) 1988. Ethnological results of the Point Barrow Expedition. Classics of Smithsonian Anthropology reprint 1988. Edited by W.W. Fitzhugh. Washington, D.C.: U.S. Government Printing Office.

https://doi.org/10.5962/bhl.title.32225 
Nelson, E.W. (1899) 1983. The Eskimo about Bering Strait. Bureau of American Ethnology, 18th Annual Report. Classics of Smithsonian Anthropology reprint 1983. Washington, D.C.: U.S. Government Printing Office.

Núñez, M. 2009. The sea giveth, the sea taketh: The role of marine resources in northern Ostrobotnia, Finland, 4000-2000 B.C. Arctic Anthropology 46(1-2):167-175. https://doi.org/10.1353/arc.0.0021

Núñez, M., and Okkonen, J. 2005. Humanizing of north Ostrobotnian landscapes during the 4th and 3rd millennia BC. Journal of Nordic Archaeological Science 15:25-38.

Olsen, B. 1994. Bosetning og Samfunn i Finnmarks Forhistorie [Settlement and society in prehistoric Finnmark]. Oslo: Universitetsforlag.

Österholm, S. 1997. Forntidens båtar - et forsøk med experimentall arkeologi [Boats in the past - a trial using experimental archaeology]. In: Burenhult, G., ed. Ajvide och den Moderna Arkeologin [Ajvide and the modern archaeology]. Falköping: Natur och Kultur. 161-171.

Pardoe, C. 1988. The cemetery as symbol. The distribution of prehistoric Aboriginal burial grounds in southeastern Australia. Archaeology in Oceania 23(1):1-16. https://doi.org/10.1002/j.1834-4453.1988.tb00178.x

Petersen, H.C. 1986. Skinboats of Greenland. Ships and boats of the North, Vol. 1. Roskilde: Viking Ship Museum.

Pettersson, M., and Wikell, R. 2014. Where sky and sea are one. Close encounters with early seafarers and seal-hunters off the Swedish Baltic coast. In: Riede, F., and Tallaavaara, M., eds. Lateglacial and Postglacial pioneers in northern Europe. BAR International Series 2599. Oxford: Archaeopress. 103-119.

Ray, P.H. (1885) 1988. Ethnographic sketch of the Natives of Point Barrow. In: Ethnological results of the Point Barrow Expedition, by J. Murdoch. Classics of Smithsonian Anthropology reprint 1988. Edited by W.W. Fitzhugh. Washington, D.C.: U.S. Government Printing Office. Lxxxvii-cv.

Renfrew, C. 1977. Alternative models for exchange and spatial distribution. In: Earle, T.K. and Ericson, J.E., eds. Exchange systems in prehistory. New York: Academic Press. 71-90. https://doi.org/10.1016/B978-0-12-227650-7.50010-9

Renouf, M.A.P. 1984. Northern coastal hunter-fishers: An archaeological model. World Archaeology 16(1):18-27. https://doi.org/10.1080/00438243.1984.9979913

- 1989. Prehistoric hunter-fishers of Varangerfjord, northeastern Norway. British Archaeological Reports International Series 487. Oxford: Archaeopress.

Renouf, M.A.P., and Bell, T. 2011. Across the tickle: The Gould Site, Port au Choix-3 and the Maritime Archaic Indian mortuary landscape. In: Renouf, M.A.P., ed. The cultural landscapes of Port au Choix. Interdisciplinary Contributions to Archaeology. New York: Springer. 43-63. https://doi.org/10.1007/978-1-4419-8324-4_3

Richardson, A. 1982. The control of productive resources on the northwest coast of North America. In: Williams, N.M., and Hunn, E.S., eds. Resource managers: Australian and North American hunter-gatherers. Canberra: Australian Institute of Aboriginal Studies. 93-112.
Robinson, B.S. 2006. Burial ritual, technology, and cultural landscape in the Far Northeast: 8600-3700 B.P. In: Sanger, D., and Renouf, M.A.P., eds. The Archaic of the Far Northeast. Orono: University of Maine Press. 341-381.

Rowley-Conwy, P. 1998. Cemeteries, seasonality and complexity in the Ertebølle of southern Scandinavia. In: Zvelebil, M., Dennell, R., and Domanska, L., eds. Harvesting the sea, farming the forest: The emergence of Neolithic societies in the Baltic region. Sheffield: Sheffield Academic Press. 193-202.

Sanger, D. 1973. Cow Point: An Archaic cemetery in New Brunswick. Mercury Series, Archaeological Survey of Canada Paper 12. Ottawa: National Museum of Man.

- 1991. Five thousand years of contact between Maine and Nova Scotia. Bulletin of the Maine Archaeological Society 31(2):55-61.

. 2010. Foraging for swordfish (Xiphias gladius) in the Gulf of Maine. In: Keenlyside, D.L., and Pilon, J.-L., eds. Painting with a broad brush: Papers in honour of James Valliere Wright. Mercury Series, Archaeology Paper 170. Ottawa: Canadian Museum of History. 1-36.

Saxe, A.A. 1970. Social dimensions of mortuary practices. PhD thesis, University of Michigan, Ann Arbor, Michigan.

Schmitt, L. 2013. A note concerning flake axes and umiaks. Oxford Journal of Archaeology 32(1):119-122. https://doi.org/10.1111/ojoa.12005

Schmitt, L., and Svedhage, K. 2016. Chronological aspects of the Hensbacka - a group of hunter-gatherers/fishers on the west coast of Sweden during the Pleistocene/Holocene transition: An example of early coastal colonization. Danish Journal of Archaeology 4(1):75-81.

https://doi.org/10.1080/21662282.2016.1141490

Schmitt, L., Larsson, S., Burdukiewicz, J., Ziker, J., Svedhage, K., Zamon, J., and Steffen, H. 2009. Chronological insights, cultural change, and resource exploitation on the west coast of Sweden during the Late Palaeolithic/Early Mesolithic transition. Oxford Journal of Archaeology 28(1):1 - 27. https://doi.org/10.1111/j.1468-0092.2008.00317.x

Service, E.R. 1962. Primitive social organization: An evolutionary perspective. New York: Random House.

. 1966. The hunters. Englewood Cliffs: Prentice-Hall.

Simonsen, P. 1959. Fundforhold og dateringer [Find conditions and dating]. In: Torgersen, J., Getz, B., and Simonsen, P., eds. Varanger-funnene I. Funn av menneskeskjeletter [The Varanger finds I. Discovery of human skeletons]. Tromsø Museums Skrifter 7, Vol 1. 5-19.

Simonsen, P. 1961. Varanger-funnene II. Fund af Udgravninger på Fjordens Sydkyst [The Varanger finds II. Finds from excavations on the fjord's south coast]. Tromsø Museums Skrifter 7, Vol. 2.

Speck, F.G. 1922. Beothuk and Micmac. Indian Notes and Monographs, edited by F.W. Hodge. New York: Museum of the American Indian, Heye Foundation

Spencer, R.F. 1959. The North Alaskan Eskimo: A study in ecology and society. Washington, D.C.: U.S. Government Printing Office.

Steward, J.H. 1955. Theory of culture change: The methodology of multilinear evolution. Urbana: Illinois University Press. 
Suttles, W. 1968. Coping with abundance: Subsistence on the Northwest Coast. In: Lee, R.B., and DeVore, I., eds. Man the hunter. Chicago: Aldine. 56-68.

Tichy, R. 1999. Monoxylon II. Plavba po 8000 letech (with English translation: Monoxylon expeditions). Hronov 1999:167-215.

Torgersen, J., Getz, B., and Simonsen, P., eds. 1959. Varangerfunnene I. Funn av Menneskeskjeletter [Varanger findings 1. Discovery of human skeletons]. Tromsø Museums Skrifter 7, Vol. 1.

Torrence, R. 1983. Time budgeting and hunter-gatherer technology. In: Bailey, G., ed. Hunter-gatherer economy in prehistory: A European perspective. Cambridge: Cambridge University Press. 11-22.

__ 2001. Hunter-gatherer technology: Macro- and microscale approaches. In: Panter-Brick, C., Layton, R.H., and Rowley-Conwy, P., eds. Hunter-gatherers: An interdisciplinary perspective. Biosocial Society Symposium 13. Cambridge: Cambridge University Press. 73-98.
Tromnau, G. 1987. Late Palaeolithic reindeer-hunting and the use of boats. In: Burdukiewicz, J.M., and Kobusciewicz, M., eds. Late Glacial in Central Europe: Culture and environment. Oddzial we Wroclawiu 5. Wroclaw: Polska Akademia Nauk. 95- 105 .

Tuck, J.A. 1976. Ancient people of Port au Choix. Newfoundland Social and Economic Studies 17. St. John's: Memorial University of Newfoundland, Institute of Social and Economic Research.

Tuck, J.A., and McGhee, R. 1976. An Archaic Indian burial mound in Labrador. Scientific American 235(5):122-129. https://doi.org/10.1038/scientificamerican1176-122

Watanabe, H. 1968. Subsistence and ecology of northern food gatherers with special reference to the Ainu. In: Lee, R.B., and DeVore, I., eds. Man the hunter. Chicago: Aldine. 69-77.

Woodburn, J. 1980. Hunters and gatherers today and reconstruction of the past. In: Gellner, E., ed. Soviet and Western anthropology. London: Duckworth. 95-117.

- 1982. Egalitarian societies. Man (N.S.) 17(3):431-451. https://doi.org/10.2307/2801707 